\title{
Pile-Raft-Soil Interaction Study by Finite Element Analysis
}

\author{
Soumya Roy \\ (Department of Civil Engineering, Meghnad Saha Institute of Technology, Kolkata, India.
}

\begin{abstract}
In the present work, a raft supported on a centrally located pile has been analyzed by through a Finite Element Model to predict the interaction behavior pile-raft and soil in piled raft foundation composite. Attempt has been made to study the effects of soil modulus, raft to pile width ratio, pile slenderness ratio and raft thickness on load sharing characteristics of piled raft foundation. Analysis showed an increase in axial load on pile with higher pile slenderness ratio for a fixed raft to pile width ratio. Whereas, higher raft thickness does not show much effect on load sharing. Side resistance along the pile length increased up to the critical depth of pile. Radius of influence of pile also seems to higher for higher pile slenderness ratios for a thinner raft.
\end{abstract}

Keywords: Piled raft foundation, Finite element analysis, soil structure interaction

\section{INTRODUCTION}

Due to modern day urbanization, engineers are more concentrating on high rise buildings in place of horizontal expansion due to higher cost of land acquisition and scarcity of good construction site. Use of raft foundation is being increasingly used for multistoried buildings, with or without basements in subsoil conditions with sand and silt deposits. If the load bearing strength of the shallow layers are inadequate for supporting high-rise constructions, medium to long load-bearing and friction piles are constructed to transfer the entire load or a part to load to intermediate deep and stiffer soil layers [1]. Even if the shear strength is adequate for giving the required bearing capacity to the raft foundation, the settlement may not be under permissible limit. For such situations, where it becomes necessary to reduce settlements, a piled raft foundation can be opted for to achieve an economic foundation system [2].

\section{LITERATURE SURVEY}

Attempts has been made by some researchers to reduce the number of piles supporting highrise constructions by sharing some portion of the superstructure load to by raft [3], [4]. Limited theoretical studies have been proposed to reduce total and differential settlements by providing the piles at specific locations under the raft. This involves rigorous analysis with exhaustive experiments to predict the interaction between pilesoil, raft-soil and raft-pile foundation system. Prediction of interactions are quite complex as described in [5] and others [6], [7], [8] and [9].

In the present study, a simple pile raft arrangement is modeled in finite element package Plaxis version 8.2. Raft supported on single pile has been modeled to predict the load sharing characteristics of the piled raft foundation simulating the condition of piles acting individually. In the analysis, pile slenderness ratio, thickness of the raft, soil modulus and raft to pile width ratio are varied to study the load sharing characteristics of the piled raft foundation.

\section{MODELING OF PILED RAFT FOUNDATION}

Modeling of the foundation soil for the piled raft system was done with 15 noded elements. Piles and raft are modeled as solid plate element [10]. The degree of tolerance and merged distance of the meshing was set to 0.01 . Regarding boundary condition, the side planes of the model are kept at great distances with a roller support. The plane at the bottom of the model is fixed as shown in Fig. 1. The complete model with 15 nodes for individual soil element is shown in Fig. 2. The global coarseness is refined as shown in Fig. 1 and Fig. 2 to minimize the effect of size of the element on the analysis results [11].

To study the axial load carried by the piles, pile slenderness ratio was increased keeping the raft to pile width ratio and modulus ratio of concrete as constant. Further for a constant applied pressure and pile slenderness ratio the ratio of raft thickness to pile diameter is varied to study the effect of raft thickness on load carried by the raft. load share of pile is studied by varying the raft width to pile diameter ratio and pile slenderness ratio

Effect of soil stiffness is studied on pile raft load share mechanism followed by skin friction mobilization on pile for increasing pile slenderness ratio. Finally, radius of influence of pile is studied by varying increasing pile length for fixed raft width to pile diameter ratio. 


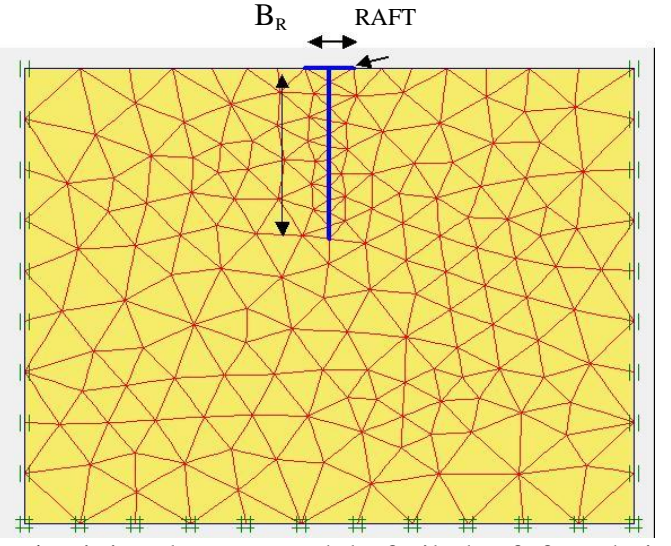

Fig. 1. Finite element model of piled raft foundation

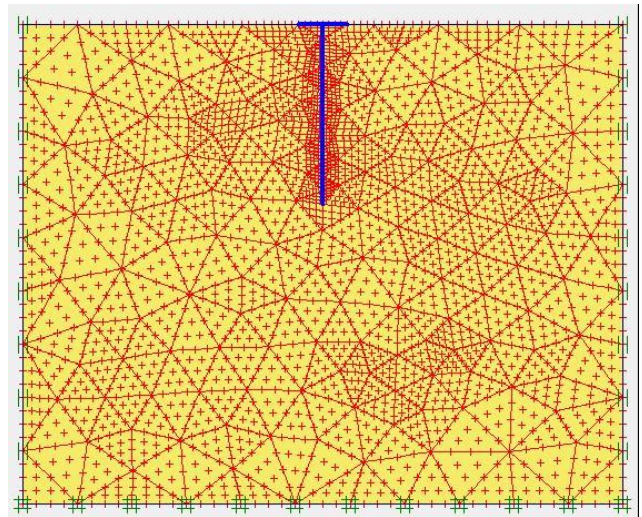

Fig. 2. Refined mesh around pile and 15 noded soil element

The variable parameters are mentioned in Table 1 for the present study. Thickness of the raft has been denoted by ' $t$ '. Width of raft is denoted by $\mathrm{Br}$. The ratio of $\mathrm{B}_{\mathrm{r}} / \mathrm{d}$ is termed as pile spacing. The length of pile is denoted by ' $\mathrm{L}$ ' and diameter of the pile is symbolized as 'd'. Poisson's ratio of soil and concrete is taken as 0.35 and 0.18 respectively.

Table 1 Variable Parameters

\begin{tabular}{|c|c|c|c|c|c|}
\hline tinm & 0.5 & 0.75 & 1.1 & 1.5 & \\
\hline $\mathrm{B}_{\mathrm{f} \text { inm }}$ & 1.2 & 2.4 & 4 & 6 & \\
\hline Lin m & 4 & 6 & 8 & 10 & 12 \\
\hline $\operatorname{din} m$ & & & 0 & & \\
\hline$E_{c}\left[\mathrm{kN} / \mathrm{m}^{3}\right.$ & & & $2 X$ & & \\
\hline $\mathrm{E}_{3} \mathrm{kN} / \mathrm{m}^{2}$ & $2 \times 10^{5}$ & $1 \times 10^{5}$ & $5 \times 10^{4}$ & $3.3 \times 10^{4}$ & $2.5 \times 10^{4}$ \\
\hline td & 1.25 & 1.875 & 2.75 & 3.75 & \\
\hline$B_{1} / d$ & 3 & 6 & 10 & 15 & \\
\hline $\mathrm{I} / \mathrm{d}$ & 25 & 40 & 50 & 62 & \\
\hline$E_{v} E_{8}$ & 200 & 400 & 600 & 800 & 1000 \\
\hline
\end{tabular}

\section{RESULTS AND DISCUSSION}

\section{Load distribution in Pile}

Figs. 3-6 shows the variation of axial load distribution along the pile length. Maximum axial load occurs within critical length from the top of pile and proportionately decrease with increase of pile depth.

The maximum load shared to the pile occurs utpo the critical length of pile i.e. 15 to 20 times diameter of the pile. 60 to $70 \%$ of the total applied pressure load is being shared to the pile where the piles are modelled as friction pile. Raft is found to carry 30 to $40 \%$ of the total applied load for the present case. Raft is found to take the initial load and then disperse it to the soil before transferring the load to the pile. There is proportionate increase in axial load distribution in pile with increase in the slenderness ratio of supporting pile for fixed ratio of soil to raft modulus, thickness, and raft width.

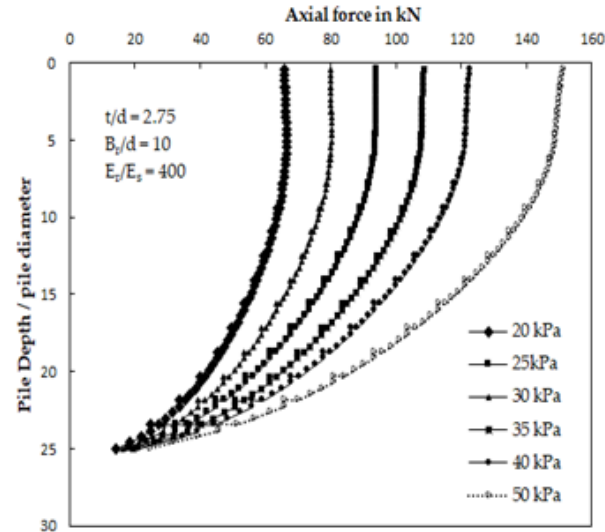

Fig. 3. Axial force distribution in pile, $L / d=25$

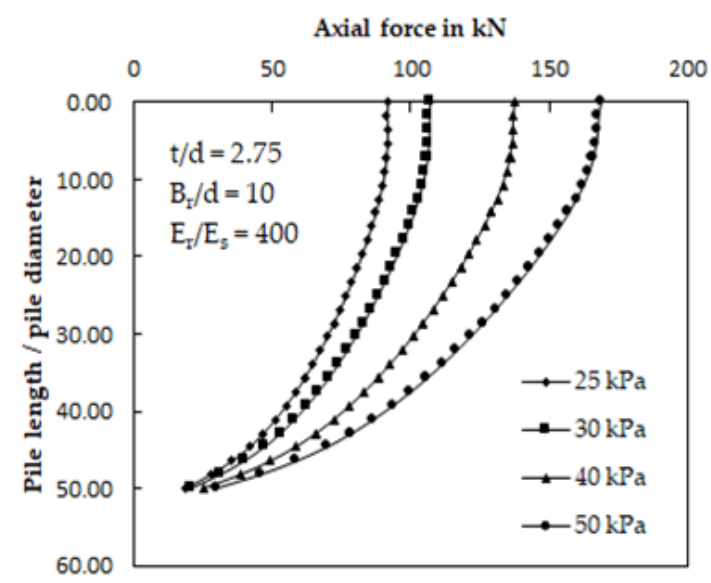

Fig. 4. Axial force distribution in pile, $\mathrm{L} / \mathrm{d}=40$ 


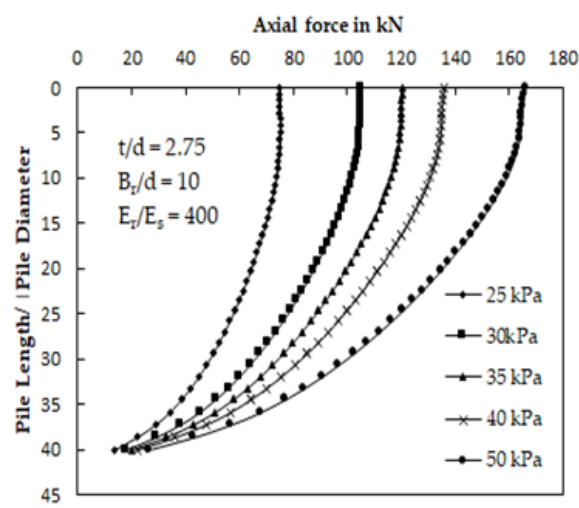

Fig. 5. Axial force distribution in pile, $\mathrm{L} / \mathrm{d}=50$

\section{Load sharing of piled raft foundation Raft thickness}

Load sharing between the raft and pile for different raft thickness and pile spacing i.e. ratio of raft width to pile diameter are plotted in Fig. 7. The percentage of load shared by the raft is found to decrease with increase of raft thickness. Raft with lower thickness is found to take more load than the thicker raft. Further, plotted data shows that increasing the raft thickness does not influence the load sharing to the pile as a whole.

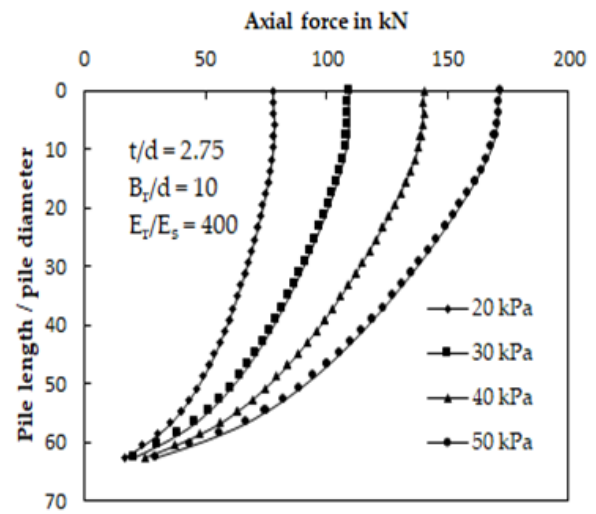

Fig. 6 Axial force distribution in pile, $\mathrm{L} / \mathrm{d}=60$

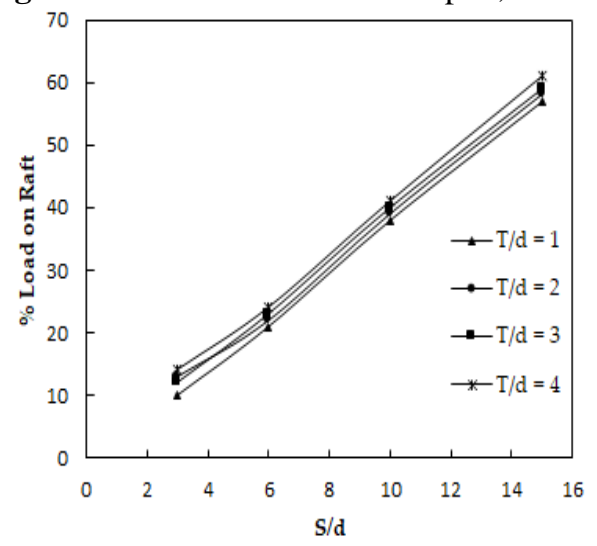

Fig. 7 Effect of raft thickness and pile spacing

\section{Pile Slenderness Ratio}

The effect of pile slenderness ratio and pile spacing under the constant pressure of $300 \mathrm{kPa}$ has been shown in Fig. 8 for the pile raft composite. It is found that increasing the pile slenderness ratio and reducing the pile spacing does not show any improvement in the percentage of load carried by the pile. Decrease in s/d ratio resulted in much lesser relative motion between the pile and surrounding soil.

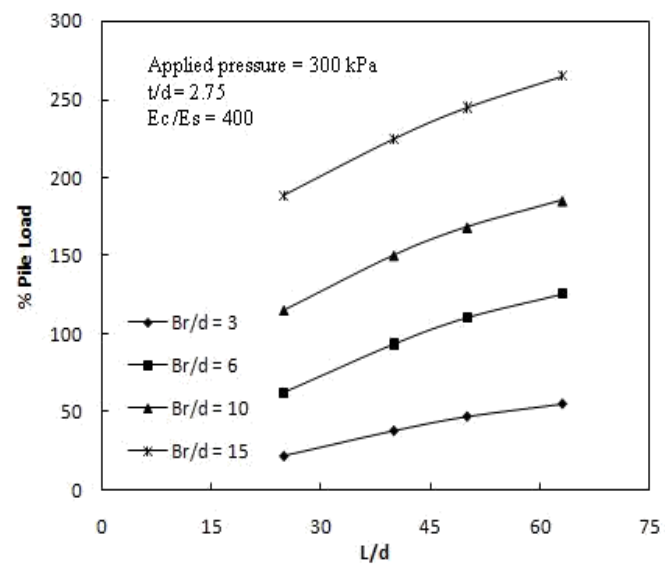

Fig. 8 Effect of $L / d$ and $B_{r} / d$ on load transfer to pile

Majority of the applied load is found to be transferred to pile due to decrease in $\mathrm{B}_{\mathrm{r}} / \mathrm{d}$ ratio. About $75 \%$ to $85 \%$ of the applied load is transferred to the piles. Whereas, increase in pile slenderness with larger $B_{r} / d$ ratio showed improvement in the percentage $\left(100 \times \mathrm{x}_{\text {pile }} / \mathrm{P}_{\text {total }}\right)$ of load carried by the pile.

Fig.9 shows effect of soil modulus and pile spacing on load shared by the pile. From the plot, it can be stated that load shared by pile is inversely proportional to the soil modulus i.e decrease in soil modulus increases in load sharing value to piles. Stiffer the soil subsoil i.e for lower $\mathrm{E}_{\mathrm{c}} / \mathrm{E}_{\mathrm{s}}$ value, there is lesser in load sharing to pile.

This is because of load transfer mechanism in to the soil and maximum of the load coming from the superstructure is getting transferred to the deeper soil through contact surface of pile, i.e. skin friction. Thus, in soft soil, whatever load comes to the raft is taking care by the pile through skin friction and alternatively, if the soil is hard soil, whatever load comes to the raft is taking care by the underneath raft soil, thus minimum effect in the pile.

\section{Development of skin friction}

Fig.10 shows the development of unit skin friction for different pile spacing. Plot shows an increase in mobilized skin friction along the pile length. 


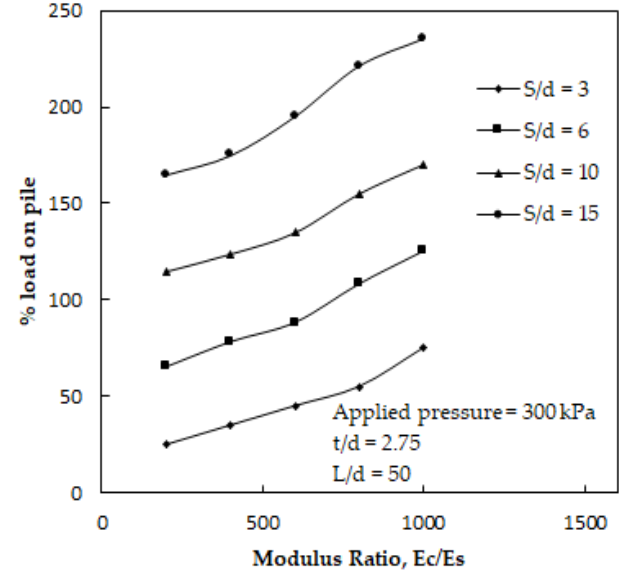

Fig. 9 Effect of Ec/Es and s/d ratio on load transfer to pile

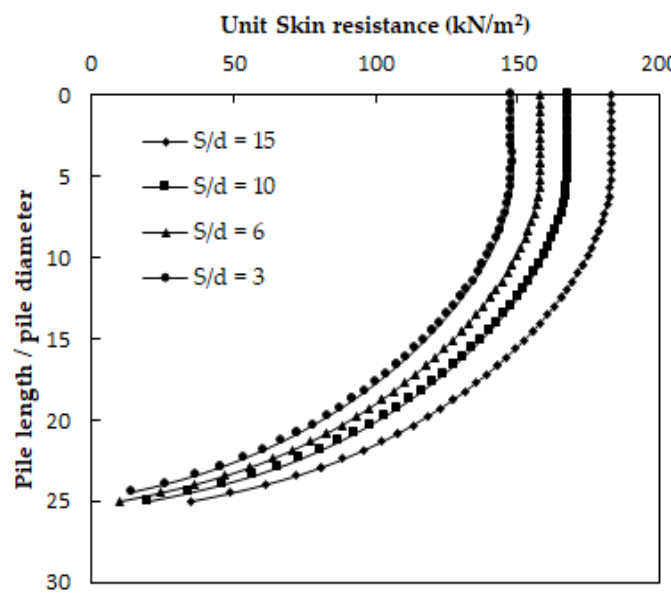

Fig. 10. Effect of Ec/Es and s/d ratio on load transfer to pile

Decrease in $\mathrm{B}_{\mathrm{r}} / \mathrm{d}$ ratio, shows proportionally decrease in development of unit of skin friction along the pile length. It shows that a fully developed unit friction of a pile in piled raft foundation can only be achieved when the piles are placed at larger spacing. Development of unit skin friction along the pile is found less below critical depths of pile. After full mobilization, the load is being transferred to the bottom of the soil through skin friction there by amount of unit skin friction proportionately decreased towards pile toe.

\section{Radius of pile influence}

To study the radius of pile influence on raft a non-dimensional plot is made in Fig. 11 between $\%$ loads carried by the raft and normalized width of raft. Fig. 8 shows that with higher values of L/d ratio the radius of pile influence increases where the $\mathrm{Br} / \mathrm{d}$ ratio is constant. Whereas lowering the $\mathrm{L} / \mathrm{d}$ ratio shows a sharp decrement in radius of pile influence. It depicts also a higher amount of load transfer to the raft for lower $\mathrm{L} / \mathrm{d}$ ratio.

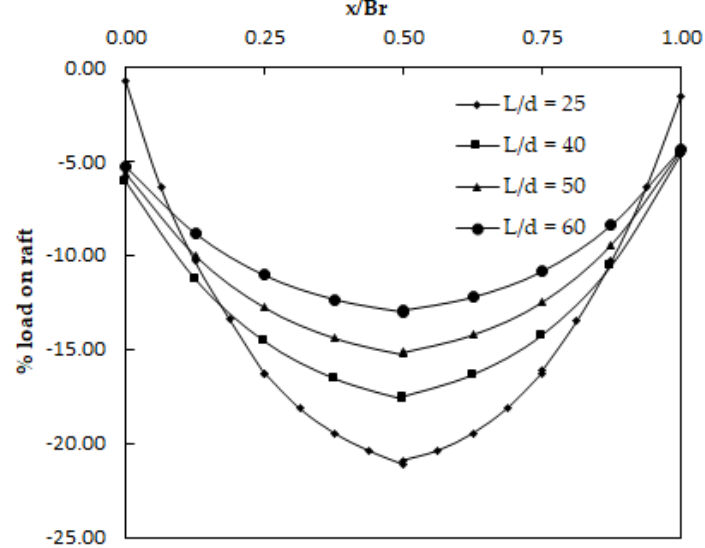

Fig. 11 Effect of L/d ratio on radius of influence of pile

\section{CONCLUSION}

Influence of pile spacing, pile slenderness ratio, raft thickness, effect of soil modulus in load sharing behavior for piled raft foundation is presented in this paper. Load sharing behavior of pile and raft is found to vary according to the stiffness of soil considering the stiffness of the raft and pile at constant. Stiffer the soil, lesser in load sharing and softer the soil, more in load shared by the pile. There is not much significant effect of increase in raft thickness in case of soft soil beyond which they are almost similar characteristic. However, unit skin friction plays a very important role on load sharing between piles and raft in raft foundation supported on friction piles. Above all, there is significant effect of pile spacing for every analysis result. Henceforth it may have concluded that adopting the pile spacing within a range of three to six times diameter of pile would keep settlement within permissible limit in large raft foundations and would economize the cost of construction of piled raft foundation.

\section{ACKNOWLEDGEMENTS}

The authors wish to thank Prof. Dr. R.B. Sahu, Dept. of Civil Engineering, Jadavpur University for allowing the usage of Plaxis Software and other resources of the department. The author is also grateful to Dr. B.C. Chattopadhyay for many valuable discussions and assistance in the interpretation of the data as presented in this paper.

\section{REFERENCES}

[1] Berezantzev, V.G., Khristoforov, V. and Golubkov., "Load bearing capacity and Deformation of Piled Foundation," Proc. $5^{\text {th }}$ Int. Conf. Soil Mech. \& Foundation Engineering, Paris, 2, pp. 11-15, 1961. 
[2] Poulos, H. G., and Davis, E. H. (1980). Pile Foundation Analysis and Design, Wiley, New York

[3] Paran Moyes, Polous H. G., Small, C. John., Badelow, F., "Piled Raft Design Process A high Rise Building on The Gold Coast, Australia”. pp. 1-9, Scholary Article, 1993.

[4] S. Roy, Chattopadhyay, B.C., and Ramendu, B. Sahu, "Piled Raft Foundation on Consolidating Soft Soil," Proc. Indian Geotechnical Conference, Kochi, India, pp. 879882, 2011.

[5] Chow. Y. K., K.Y. Young., and Shen, W.K., "Analysis of Piled Raft Foundation Using Variational Approach.” International Journal of Geotechnical Engineering," Volume 1, Number 2, pp. 129-147, 2001.

[6] Poulos, H. G. "Piled Raft Foundation Design and Application" Geotechnique, Volume 51, Number 2, pp. 95-113, 2001.

[7] C. J. Small, H. H., Zhang., "Behavior of Piled Raft Foundation under Lateral and Vertical Loading", Int. Journal of Geomechanics, Volume 2, Number 1, pp 29-45, 2002.

[8] O. Ruel, " Numerical Study on Behavior of Piled Raft" Int. Journal of Geomechanics, ASCE, vol. 4, no. 2, pp. 59-68, 2004.

[9] D.K. Maharaj and S.R. Gandhi, "Non-linear Finite Element Analysis of Piled Raft Foundations," Proc. ICE, Geotechnical Engineering, Issue GE3, pp. 107-113, 2004.

[10] E.Y. N OH, M. Huang, C., Surakar, R. Adamee and S Balasubramanium, "Finite Element Modeling for Piled Raft Foundation in Sand," $11^{\text {th }}$ Proc. Computational Intelligence in Scheduling (SCIS '07), pp. 57-64, Apr. 2007, doi:10.1109/SCIS.2007.367670.

[11] F. Zheng., D.G. Lin., "A Numerical Study of Piled Raft Foundation," J. of The Chinese Institute of Engineers, vol. 29, No 6, pp 1091-1097. 